\title{
The Impact of Psychological Empowerment and Organizational Commitment on Innovation Performance-Based University data analysis
}

\author{
Wu Xiaowei ${ }^{1}$, Li Juan ${ }^{2}$ \\ ${ }^{1}$ Human Resources Office, Jinan University, Guangzhou, China, 510632 \\ ${ }^{2}$ School of Stomatology, Jinan University, Guangzhou, China, 510632
}

Keywords: Psychological empowerment, Organizational commitment, Innovation performance

\begin{abstract}
In this study, from the perspective of the psychological empowerment of university teachers, a mechanism model of psychological empowerment and organizational commitment to innovation performance was constructed. Through the questionnaire survey, a total of 467 valid questionnaires were collected. The result is analyzed by using SPSS and AOMS statistical software. The conclusions are as follows: (1) There was a significant positive correlation between psychological empowerment and innovation performance. (2) Psychological empowerment and organizational commitment were significant. (3) There is a significant positive correlation between organizational commitment and innovation performance. (4) Organizational commitment is an important antecedent variable of innovation performance and plays an intermediary role between psychological empowerment and innovation performance. The results of this study show that if knowledge-intensive organization leaders strengthen their psychological empowerment to employees, it will help to enhance employees' organizational commitment. And it will greatly improve the innovation performance of knowledge-intensive organizations.
\end{abstract}

\section{Introduction}

For the first time, Thomas and Velthous put forward the concept of psychology empowerment. They point out that psychological empowerment is the intrinsic motivation embodied in the process of participation creation. And they sum up the four dimensions that affect psychological empowerment: meaning of work, autonomy Self-determination, self-efficacy, work impact [1]. Research shows that psychological empowerment has a positive impact on employees' intrinsic motivation, and intrinsic motivation is considered as an effective predictive creativity. The concept of Organizational Commitment was put forward by Becker [2]. Becker thought that organizational commitment is the manifestation of emotion. Employees gradually increase their affection on the organization and form a feeling of dedication to the organization. Employees do not want to leave the organization mainly because employees have a more emotional dependence on the organization.

\section{The literature review}

Frick argues that college teachers are one of knowledge workers and workers with special brainpower, which have the common characteristics of knowledge workers [3]. Based on the results of Thomas and Velthouse's research, Spreitzer perfected and extended the concept of psychological empowerment. He developed and validated a four-dimensional scale [4]. The research by Lin (2011) shows that business leaders should not only increase employees 'innovative behavior by shaping their own transformational leadership, but also are good at creating a sense of psychological empowerment for employees and enhancing employees' self-esteem and self-esteem. And it's well to improve employee innovation behavior [5]. Spreitzer, Zhang \& Bartol [6] and other scholars all think that when employees recognize the significance of the work or its own development, then they are willing to use more time and more efforts to further study the issue, and they may try new ways of working, put forward more and broader work ideas.

Through above analysis, this paper puts forward the theoretical model of the relationship model 
between psychological empowerment and university teachers' innovation performance, as shown in Figure 1:

\begin{tabular}{|c|c|c|}
\hline $\begin{array}{c}\text { Psychological } \\
\text { empowerment } \\
\text { Self-efficacy } \\
\text { Autonomy } \\
\text { Meaning of work } \\
\text { Work impact }\end{array}$ & $\begin{array}{c}\text { Organizational } \\
\text { commitment } \\
\text { Emotional commitment } \\
\text { Continued commitment } \\
\text { Regulatory } \\
\text { commitment }\end{array}$ & $\begin{array}{c}\text { Innovative } \\
\text { performance } \\
\text { Willingness to } \\
\text { innovate } \\
\text { innovative behavior } \\
\text { Innovative result }\end{array}$ \\
\hline
\end{tabular}

Figure 1 Theoretical model of the relationship between mental empowerment, organizational commitment and innovation performance

\section{Research methods}

\subsection{The research object}

From January to February in 2017, paper questionnaires and e-questionnaires were distributed at some universities. And a total of 600 questionnaires were distributed on a pro-rata basis at $\mathrm{N}$ University's colleges. 492 questionnaires are now being collected, 25 non-responsable and incomplete invalid questionnaires are removed, 467 valid questionnaires are obtained. And the effective questionnaire rate is $94.92 \% .44 .8 \%$ and $55.2 \%$ of male and female sample respectively, $56.3 \%$ of teachers, $15.8 \%$ of managers, $23.8 \%$ of experimenters, $3.6 \%$ of full-time researchers and $0.5 \%$ of other staff members; $66.6 \%$ in the 50 -year-old age range, $11.1 \%$ of them are under 30 years of age, $22.3 \%$ of whom are over 50 years of age; $94.3 \%$ of whom work more than 10 years in school and 5.8\% under 10 years. Arts and sciences are accounted for $49 \%$ and 51\%, respectively, and their distribution tended to be consistent.

\subsection{Measurement tools}

The measurement scale of this study is based on Likert's 5-point measurement. The answers range from 1 to 5 for "totally disagree" to "completely agree".

According to the situation of colleges and universities, as well as the needs of this study, we designed the scale of 8 items. The data used in this study meet the research requirements. (Shown in Table 1)

Table 1 Confidence tables for each study scale

\begin{tabular}{|c|c|}
\hline Scale & Total credit \\
\hline Psychological empowerment & 0.940 \\
\hline Organizational commitment & 0.927 \\
\hline Innovative performance & 0.817 \\
\hline
\end{tabular}

\section{The correlation analysis of variables}

The results show that: (1) There is a significant positive correlation between self-efficacy, job autonomy, job impact and innovation performance in psychological empowerment dimensions. The correlation coefficients are $0.411,0.521,0.431$ and 0.580 , respectively. (2) There is a significant positive correlation between the emotional commitment, the normative commitment, the sustained commitment and the innovation performance. The correlation coefficients are $0.553,0.707$ and 0.553 respectively. (Shown in Table 2) 
Table 2 Innovative Performance and Psychological Empowerment, Organizational Commitment Dimensions Relevant Analysis

\begin{tabular}{|c|c|c|c|c|c|c|c|c|}
\hline variable & Self-efficacy & Autonomy & $\begin{array}{l}\text { Meaning } \\
\text { of work }\end{array}$ & $\begin{array}{l}\text { Work } \\
\text { impact }\end{array}$ & $\begin{array}{l}\text { Emotion } \\
\text { commitment }\end{array}$ & $\begin{array}{l}\text { Regulate } \\
\text { the } \\
\text { promise }\end{array}$ & $\begin{array}{l}\text { Continued } \\
\text { commitment }\end{array}$ & $\begin{array}{l}\text { Innovative } \\
\text { performance }\end{array}$ \\
\hline Self-efficacy & 1 & & & & & & & \\
\hline Autonomy & $\begin{array}{c}0.726 \\
* *\end{array}$ & 1 & & & & & & \\
\hline $\begin{array}{l}\text { Meaning of } \\
\text { work }\end{array}$ & $0.884 * *$ & $\begin{array}{c}0.715 \\
* *\end{array}$ & 1 & & & & & \\
\hline Work impact & $\begin{array}{c}0.768 \\
* * \\
\end{array}$ & $\begin{array}{c}0.698 \\
* * \\
\end{array}$ & $0.831^{* *}$ & 1 & & & & \\
\hline $\begin{array}{l}\text { Emotion } \\
\text { commitment }\end{array}$ & $\begin{array}{c}0.415 \\
* * \\
\end{array}$ & $0.464^{* *}$ & $0.361 * *$ & $\begin{array}{c}0.525 \\
* * \\
\end{array}$ & 1 & & & \\
\hline $\begin{array}{l}\text { Regulate the } \\
\text { promise }\end{array}$ & $\begin{array}{c}0.566 \\
* *\end{array}$ & $\begin{array}{c}0.689 \\
* * \\
\end{array}$ & $0.451^{* *}$ & $\begin{array}{c}0.694 \\
* *\end{array}$ & $0.717^{* *}$ & 1 & & \\
\hline $\begin{array}{l}\begin{array}{l}\text { Continued } \\
\text { commitment }\end{array} \\
\end{array}$ & $\begin{array}{c}0.452 \\
* * \\
\end{array}$ & $\begin{array}{c}0.517 \\
* *\end{array}$ & $0.452 * *$ & $\begin{array}{c}0.605 \\
* * \\
\end{array}$ & $0.676^{* *}$ & $0.684 * *$ & 1 & \\
\hline $\begin{array}{l}\text { Innovative } \\
\text { performance }\end{array}$ & $\begin{array}{c}0.411 \\
* *\end{array}$ & $\begin{array}{c}0.521 \\
* *\end{array}$ & $0.431 * *$ & $\begin{array}{c}0.580 \\
* *\end{array}$ & $0.553 * *$ & $0.707 * *$ & $0.553 * *$ & 1 \\
\hline
\end{tabular}

Note: "**" indicates significant correlation at 0.01 level (two-sided test)

Innovative Performance and Self-Efficacy $(B=0.320, \beta=0.302, p<0.001)$, autonomy $(B=0.278$, $\beta=0.251, p<0.001))$, Work effect $(B=0.749, \beta=0.642, p<0.001)$. From this analysis, there is a positive correlation between self-efficacy, autonomy, job meaning and work performance and innovation performance. Suppose H1a, H1b, H1c, H1d, Set up $(B=0.201, \beta=0.273, p<0.001)$ and autonomy $(\mathrm{B}=0.307, \beta=0.370, \mathrm{p}<0.001)$ and $(\mathrm{B}=0.685, \beta=0.782, \mathrm{p}<0.001)$. Based on this analysis, there is a positive correlation between self-efficacy, autonomy, job meaning, job impact and organizational commitment of psychological empowerment. If H2a, H2b, H2c, H2d are established, $(B=0.244, \beta=0.248, p<0.05)$, standardized commitment $(B=0.532, \beta=0.595, p<0.001)$ and sustained commitment $(\mathrm{B}=0.216, \beta=0.229, \mathrm{p}<0.05)$. Assuming that both H3a, H3b and H3c are established, there is a positive correlation between the commitment of organizational commitment, normative commitment, and sustained commitment and innovation performance, (Shown in Table 3)

Table 3 Regression analysis of the relationship between innovation performance and psychological empowerment and organizational commitment

\begin{tabular}{|c|c|c|c|c|c|c|}
\hline \multirow{2}{*}{ Variable } & \multicolumn{3}{|c|}{ Innovation Performance } & \multicolumn{3}{|c|}{ Organizational Commitment } \\
\hline & $\mathrm{B}$ & $\beta$ & Sig. & $\mathrm{B}$ & $\beta$ & Sig. \\
\hline \multicolumn{7}{|c|}{ Explanatory variables } \\
\hline Self-efficacy & $0.320 * * *$ & $0.302 * * *$ & 0.000 & $0.201^{* * *}$ & $0.273 * * *$ & 0.000 \\
\hline Autonomy & $0.278 * * *$ & $0.251^{* * *}$ & 0.000 & $0.307 * * *$ & $0.370 * * *$ & 0.000 \\
\hline $\begin{array}{l}\text { Meaning of } \\
\text { work }\end{array}$ & $0.526 * * *$ & $0.481^{* * *}$ & 0.000 & $0.564 * * *$ & $0.688 * * *$ & 0.000 \\
\hline Work impact & $0.749 * * *$ & $0.642 * * *$ & 0.000 & $0.685 * * *$ & $0.782 * * *$ & 0.000 \\
\hline $\begin{array}{c}\text { Emotion } \\
\text { commitment }\end{array}$ & $0.244^{*}$ & $0.248^{*}$ & 0.040 & & & \\
\hline $\begin{array}{l}\text { Regulate the } \\
\text { promise }\end{array}$ & $0.532 * * *$ & $0.595^{* * *}$ & 0.000 & & & \\
\hline $\begin{array}{c}\text { Continued } \\
\text { commitment }\end{array}$ & $0.216^{*}$ & $0.229 *$ & 0.025 & & & \\
\hline
\end{tabular}

In model 1 , this is the relationship between innovation performance and self-efficacy $(\mathrm{B}=0.320$, $\beta=0.302, p<0.001)$, autonomy $(B=0.278, \beta=0.251, p<0.001)$. The regression coefficients between working effects $(\mathrm{B}=0.749, \beta=0.642, \mathrm{p}<0.001)$ were significant. In model 2 , organizational 
commitment entered the model as an intermediary variable. Although innovation performance was significantly correlated with organizational commitment $(B=0.596, \beta=0.560, p<0.001)$, it had no significant effect on self-efficacy in all dimensions of psychological empowerment $(B=0.085$, $\beta=0.097, p<0.1)$, working influence $(B=0.125, \beta=0.241, p<0.01)$. The significant relationship between psychological empowerment and innovation performance was significantly weakened, which fully demonstrated the intermediary role of organizational commitment. Therefore, it is assumed that $\mathrm{H} 4$ verification is established. (Shown in Table 4)

Table 4 Intermediary test results on the relationship between organizational commitment and psychological empowerment and innovation performance

\begin{tabular}{|c|l|l|l|l|c|}
\hline \multirow{2}{*}{ variable } & \multicolumn{5}{|c|}{ Innovative performance } \\
\cline { 2 - 6 } & \multicolumn{2}{|c|}{ Model 1 } & \multicolumn{3}{c|}{ Model 2 } \\
\cline { 2 - 6 } & \multicolumn{7}{|c|}{ B } & \multicolumn{1}{|c|}{$\beta$} & B & $\beta$ & Sig. \\
\hline \multicolumn{7}{|c|}{ Explanatory variables } \\
\hline Self-efficacy & $0.320^{* * *}$ & $0.302^{* * *}$ & $0.176^{* *}$ & $0.224^{* *}$ & 0.003 \\
\hline Autonomy & $0.278^{* * *}$ & $0.251^{* * *}$ & $0.125^{* * *}$ & $0.141^{* * *}$ & 0.000 \\
\hline Meaning of work & $0.526^{* * *}$ & $0.481^{* * *}$ & $0.085^{*}$ & $0.097^{*}$ & 0.027 \\
\hline Work impact & $0.749^{* * *}$ & $0.642^{* * *}$ & $0.221^{* *}$ & $0.237^{* *}$ & 0.001 \\
\hline \multicolumn{7}{|c|}{ Mediation variables } \\
\hline $\begin{array}{c}\text { Organizational } \\
\text { commitment }\end{array}$ & \multicolumn{7}{|c|}{$0.596^{* * *}$} & $0.560^{* * *}$ & 0.000 \\
\hline
\end{tabular}

Note: ${ }^{+} \mathrm{p}<0.1,{ }^{*} \mathrm{p}<0.05,{ }^{* *} \mathrm{p}<0.01,{ }^{* * *} \mathrm{p}<0.001$

\section{Conclusions}

Conclusion 1: Psychological empowerment has a crucial impact on innovation performance

The impact of work impact on innovation is very significant. The influence size is directly related to the innovation motivation of knowledge workers, especially for innovation results. After verification, there is a positive correlation between all dimensions of psychological empowerment and innovation performance in this study, so there is a positive correlation between psychological empowerment and innovation performance.

Conclusion 2: This study again verifies the impact of mental empowerment on organizational commitment

Based on the researches of scholars at home and abroad, this study makes a regression analysis of knowledge workers (college teachers) of different genders, identities, ages, working years, titles. There is a strong correlation between dimensions and organizational commitment.

Conclusion 3: This study validates the relationship between organizational commitment and innovation performance, and the intermediary role of organizational commitment between psychological empowerment and innovation performance

In the gradually increasing of staff psychological empowerment, their commitment to the organization is also improved, at the same time staff innovation will also increase.

\section{References}

[1] Thomas K W, Velthouse B A. Cognitive elements of empowerment: An "interpretive” model of intrinsic task motivation [J]. Academy of Management Review.1990, 4: 666-681.

[2] Becker H S. Notes on the Concept of Commitment[J]. American Journal of Sociology.1960, 66:132-42.

[3] Frick K. Worker influence on voluntary OHS management systems - A review of its ends and means [J]. Safety Science. 2011, 7: 974-987. 
[4] Spreitzer GM. Individual empowerment in the workplace: Dimensions, measurement, validation [J]. Academy of Management Journal.1995, 38:1442-1465.

[5] Lin. Psychological empowerment as the intermediary between the leadership style and employee innovation behavior research: Z company as an example [D]. Zhejiang University. 2011.

[6] Zhang XM, Bartol KM. Linking Empowering Leadership and Employee Creativity: The Influence of Psychological Empowerment, Intrinsic Motivation, and Creative Process Engagement [J]. Academy of Management Journal.2010, 1: 107-128. 